\title{
Five Decades of Research on Opioid Peptides: Current Knowledge and Unanswered Questions $\$$
}

\author{
Lloyd D. Fricker, Elyssa B. Margolis, Ivone Gomes, and Lakshmi A. Devi \\ Department of Molecular Pharmacology, Albert Einstein College of Medicine, Bronx, New York (L.D.F.); Department of \\ Neurology, UCSF Weill Institute for Neurosciences, San Francisco, California (E.B.M.); and Department of Pharmacological \\ Sciences, Icahn School of Medicine at Mount Sinai, New York, New York (I.G., L.A.D.)
}

Received January 4, 2020; accepted May 6, 2020

\section{ABSTRACT}

In the mid-1970s, an intense race to identify endogenous substances that activated the same receptors as opiates resulted in the identification of the first endogenous opioid peptides. Since then, $>20$ peptides with opioid receptor activity have been discovered, all of which are generated from three precursors, proenkephalin, prodynorphin, and proopiomelanocortin, by sequential proteolytic processing by prohormone convertases and carboxypeptidase $\mathrm{E}$. Each of these peptides binds to all three of the opioid receptor types $(\mu, \delta$, or $\kappa)$, albeit with differing affinities. Peptides derived from proenkephalin and prodynorphin are broadly distributed in the brain, and mRNA encoding all three precursors are highly expressed in some peripheral tissues. Various approaches have been used to explore the functions of the opioid peptides in specific behaviors and brain circuits. These methods include directly administering the peptides ex vivo (i.e., to excised tissue) or in vivo (in animals), using antagonists of opioid receptors to infer endogenous peptide activity, and genetic knockout of opioid peptide precursors. Collectively, these studies add to our current understanding of the function of endogenous opioids, especially when similar results are found using different approaches. We briefly review the history of identification of opioid peptides, highlight the major findings, address several myths that are widely accepted but not supported by recent data, and discuss unanswered questions and future directions for research.

\section{SIGNIFICANCE STATEMENT}

Activation of the opioid receptors by opiates and synthetic drugs leads to central and peripheral biological effects, including analgesia and respiratory depression, but these may not be the primary functions of the endogenous opioid peptides. Instead, the opioid peptides play complex and overlapping roles in a variety of systems, including reward pathways, and an important direction for research is the delineation of the role of individual peptides.

\section{Introduction}

In the 1960s, several lines of evidence suggested the existence of receptors that bound opiates and were responsible for their physiologic effects. A logical assumption was that these receptors did not exist to bind a plant compound but instead bound endogenous molecules. In 1964, the peptide lipotropin was first described ( $\mathrm{Li}, 1964)$. Although lipotropin does not have opioid-like activity, it was subsequently found to represent an intermediate in the production of $\beta$-endorphin, which does have opioid activity (Lazarus et al., 1976; $\mathrm{Li}$ and

The writing of the manuscript was funded in part by National Institutes of Health [Grants DA008863 and NS026880 (to L.A.D.) and AA026609 (to E.B.M.)]

https://doi.org/10.1124/mol.120.119388.

S This article has supplemental material available at molpharm. aspetjournals.org.
Chung, 1976). In the mid-1970s two endogenous opioid peptides were identified and named Met- and Leuenkephalin (Hughes et al., 1975). Soon after, two additional opioid peptides were found and named dynorphin A and dynorphin B (Goldstein et al., 1979; Minamino et al., 1980). Since this time, a number of additional opioid peptides have been identified in brain or other tissues and the field has greatly expanded, with over 40,000 publications on opioid peptides. In addition to the endogenous opioid peptides that are the focus of this review, a number of exogenous opioid-like peptides have been discovered in milk proteins (casomorphins), other food sources (e.g., exorphins), and frog skin (e.g., deltorphins). Other peptides reported to have opioid activity include endomorphin, kyotorphin, and opiorphin. Although endomorphin was reported to exist in brain (Zadina et al., 1997), years of effort to identify its precursor have not been

ABBREVIATIONS: $\alpha$-MSH, $\alpha$-melanocyte stimulating hormone; ACTH, adrenocorticotrophic hormone; AgRP, Agouti-related peptide; DAMGO, [D$\left.\mathrm{Ala}^{2}, \mathrm{~N}-\mathrm{MePh} \mathrm{e}^{4}, \mathrm{Gly}-\mathrm{ol}\right]$-enkephalin; DOR, $\delta$ opioid receptor; KOR, $\kappa$ opioid receptor; MOR, $\mu$ opioid receptor; PDYN, prodynorphin; PENK, proenkephalin; PET, positron-emission tomography; PNOC, pronociceptin; POMC, proopiomelanocortin. 
successful, and without evidence that this peptide is produced, endomorphin is not widely accepted as an endogenous peptide. Kyotorphin and opiorphin do not bind directly to opioid receptors; their mechanism of action is thought to be due in part to inhibition of enzymes that degrade enkephalins and/or other opioid peptides (Bosler et al., 2014; Perazzo et al., 2017).

The present review is a brief overview of the field of endogenous peptides that bind to opioid receptors. A major focus is the current status of long-standing assumptions, some of which are myths that persist despite evidence to the contrary. We conclude with a discussion of several important directions for further research.

\section{Opioid Peptides, from Precursors to Bioactive Molecules}

All endogenous peptides that bind to opioid receptors are derived from three precursors: proenkephalin (PENK), prodynorphin (PDYN), and proopiomelanocortin (POMC). Each opioid peptide precursor is processed into a variety of peptides within the secretory pathway (Fig. 1). Some of these peptides bind to opioid receptors: $\mu$ (MOR), $\delta$ (DOR), and $\kappa$ (KOR). Other peptides produced from the three precursors act on other receptors, such as the POMC-derived peptides adrenocorticotropic hormone (ACTH) and $\alpha$-melanocyte-stimulating hormone ( $\alpha$-MSH), which bind to the various melanocortin receptors (Dores et al., 2016). In addition to these, a fourth gene $(P N O C)$ encodes the precursor of the peptide named nociceptin (also known as orphanin FQ); this precursor shares amino acid sequence homology with the three opioid peptide precursors in the N-terminal domain (Supplemental Fig. 1). The receptor for nociceptin also has sequence homology to the three opioid receptors. Nociceptin and the nociceptin receptor interact with opioid systems (Toll et al., 2016), but because nociceptin is not considered an opioid peptide, it is not the focus of the present review.

The diversity of opioid peptides is partly due to differential processing of the three precursors into products of different lengths as well as variable post-translational modifications, such as phosphorylation and acetylation (Fricker, 2012). Proteolytic processing also occurs after the peptides are secreted. Though some of the extracellular cleavages degrade the peptide, other cleavages serve to alter the receptorbinding activity, in some cases enhancing the binding affinity for a particular receptor (Fricker, 2012). Thus, the processing of the peptides is a complex process that influences the resulting bioactivity.

The first processing step, removal of the N-terminal signal peptide, is mediated by the signal peptidase and occurs in the endoplasmic reticulum during translation of the precursor (Tuteja, 2005). Glycosylation at specific Asn residues in proenkephalin and POMC occurs in the endoplasmic reticulum, and in the Golgi, these carbohydrate side chains are modified (Fricker, 2012). Proteolytic processing by endopeptidases and exopeptidases begins to a small extent in late Golgi/
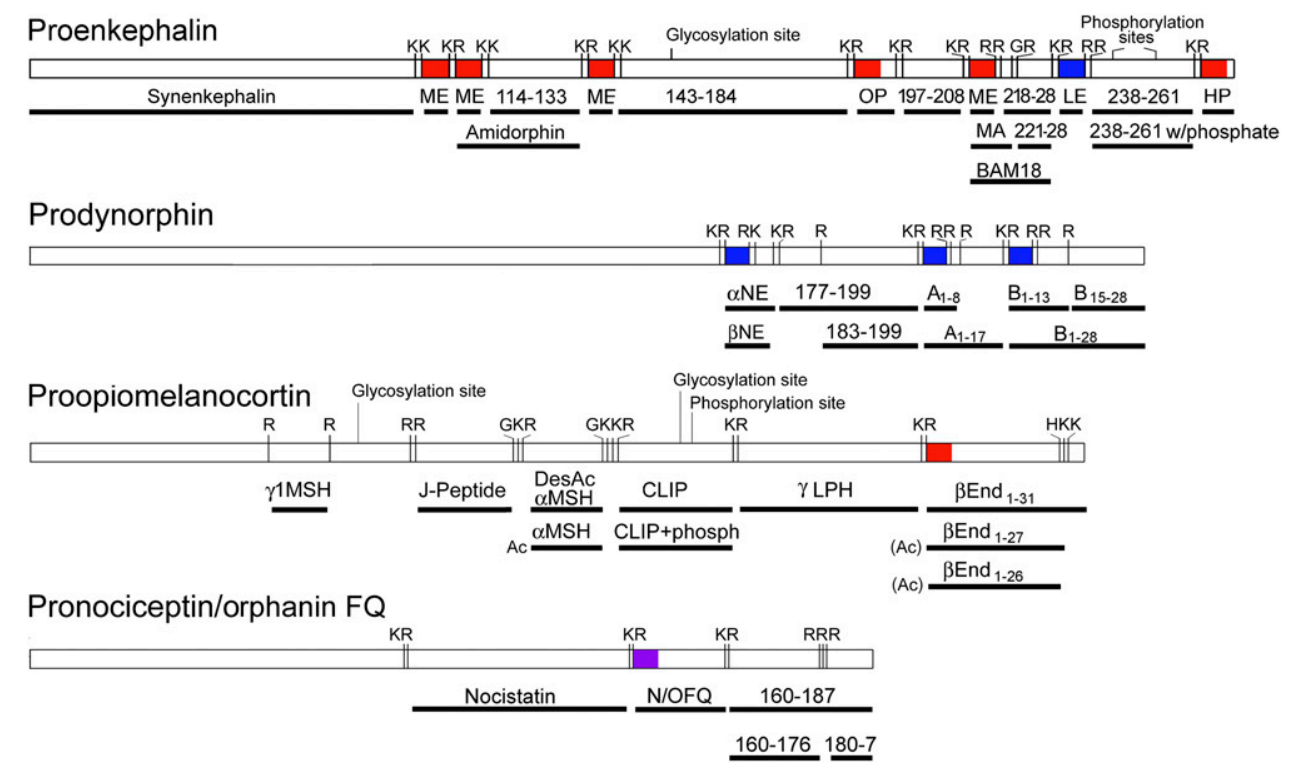

Fig. 1. Representative peptides derived from mouse proenkephalin, prodynorphin, proopiomelanocortin, and pronociceptin/orphanin FQ. Major cleavage sites (K, Lys; R, Arg) are indicated, along with glycine $(\mathrm{G})$ that is converted into C-terminal amide residues. All three of the $\beta$-endorphin peptides $(1-31,1-27$, and 1-26) are detected with and without N-terminal acetylation, as is $\alpha$-MSH (the name $\alpha$-MSH refers to the peptide with an N-terminal acetyl group; the peptide without the acetyl group is named des-acetyl- $\alpha$-MSH). Peptides without common names are referred to by number. In some cases, the number is based on the name assigned to the peptide (i.e., dynorphin $\mathrm{B}_{15-28}$, which is the $\mathrm{C}$-terminal part of dynorphin $\mathrm{B}_{1-28}$ after cleavage to produce dynorphin $\mathrm{B}_{1-13}$ ). For peptides without formal names, the number refers to the numbering of the preprohormone (i.e., proenkephalin 143-184). These numbers include the signal peptide, which is removed prior to formation of the prohormone. Regions of the precursor that contain the Metenkephalin sequence YGGFM are shown in red, regions that contain the Leu-enkephalin sequence YGGFL are shown in blue, and the region of pronociceptin/orphanin FQ that contains the pentapeptide sequence FGGFT is show in purple. However, all of these regions are not cleaved into the pentapeptides, especially $\beta$-endorphin and nociceptin/orphanin $\mathrm{FQ}$, which lack consensus cleavage sites at the appropriate positions. Note that the precursors/peptides shown here are mouse; other species have differences in specific peptides (e.g., dynorphin $\mathrm{B}_{1-29}$ in humans, $\mathrm{B}_{1-28}$ in mouse) or cleavage sites (e.g., $\beta$-MSH is a major cleavage product of human POMC but is not produced in mouse because of the absence of the appropriate cleavage site in mouse POMC). CLIP, corticotropin-like intermediate lobe peptide; End, endorphin; HP, heptapeptide; J-peptide, joining-peptide; LE, Leu-enkephalin; LPH, lipotropin; MA, metorphamide; ME, Met-enkephalin; MSH, melanocyte-stimulating hormone; NE, neoendorphin; N/OFQ, nociceptin, also known as orphanin FQ; OP, octapeptide. 
early secretory vesicles, but the vast majority of the processing occurs following packaging of the precursors and their processing enzymes into the regulated secretory vesicles and subsequent acidification of the vesicles (Fricker, 2012).

Proteolytic processing within the secretory pathway primarily occurs at cleavage sites containing one or more basic amino acids (Lys, Arg) and is mediated by two groups of enzymes: endopeptidases and carboxypeptidases. Endopeptidases initially cleave on the C-terminal side of the basic residues, producing intermediates containing C-terminal basic residues (Zhou et al., 1999; Hoshino and Lindberg, 2012). These basic residues are subsequently removed by a carboxypeptidase with specificity for basic residues; an exception is peptides that contain a Pro in the penultimate position, such as $\alpha$-neoendorphin, which ends in the sequence Pro-Arg (Fricker, 2004). The presence of the penultimate Pro slows down the carboxypeptidase activity by several orders of magnitude, and the result is the presence of two peptides in roughly comparable levels: one with the basic residue attached (e.g., $\alpha$-neoendorphin) and one without (e.g., $\beta$-neoendorphin) (Seizinger et al., 1984; Höllt, 1986; Fricker, 2004). Within the late Golgi, the primary endopeptidases are furin and related enzymes, followed by carboxypeptidase $\mathrm{D}$, but these enzymes contribute only a small amount to the cleavage of the opioid peptide precursors (Fricker, 2012). The major opioid peptideprocessing enzymes are prohormone convertase 1, prohormone convertase 2 , and carboxypeptidase $\mathrm{E}$. All three of these enzymes are activated by the acidic $\mathrm{pH}$ and elevated $\mathrm{Ca}^{2+}$ levels in maturing secretory vesicles (Fricker, 2012; Hoshino and Lindberg, 2012).

Following the proteolytic processing steps, the C-terminus of some peptides is amidated by peptidylglycine- $\alpha$-amidating monooxygenase (Fricker, 2012; Kumar et al., 2016). This enzyme recognizes peptides with a C-terminal Gly residue and removes the carbons of the Gly, leaving behind the nitrogen as an amide group on the C-terminus. Any peptide in the regulated secretory pathway that contains a C-terminal Gly is a substrate for the amidating monooxygenase, including two nonopioid POMC-derived peptides ( $\alpha$-MSH and joiningpeptide) and one opioid peptide derived from PENK; this peptide was named metorphamide and is also known as adrenorphin (Weber et al., 1983). Another amidated PENKderived peptide with activity at opioid receptors was found in Bos taurus adrenal glands and named amidorphin (Seizinger et al., 1985). However, this peptide is only amidated in some species because the Gly residue required for amidation is not highly conserved. Humans, mice, and most other mammalian species have an Ala in place of the Gly, and therefore in these species, PENK is processed into "amidorphin" that is one residue longer and is not amidated.

The N-terminus of some peptides has been found to be acetylated, but unlike C-terminal amidation, the $\mathrm{N}$-terminal acetylation is highly variable, and there is not a clear consensus sequence (Fricker, 2012). Of all peptides derived from PENK, PDYN, and POMC, only the POMC-derived peptides $\alpha$-MSH and $\beta$-endorphin are known to be acetylated. The enzyme that performs this modification has not been conclusively identified. Though acetylated $\alpha$-MSH is active and binds to melanocortin receptors, the $\mathrm{N}$-terminal acetylation of $\beta$-endorphin eliminates the ability of this peptide to bind to opioid receptors (Akil et al., 1984). A PENK-derived peptide named "peptide B" and a shorter form of this peptide corresponding to residues 238-261 (Fig. 1) are phosphorylated, but the function of this modification is not known (D'Souza and Lindberg, 1988). A POMC-derived peptide named corticotropin-like intermediate lobe peptide is also phosphorylated. Peptidomic analyses of mouse brain have detected both the phosphorylated and nonphosphorylated forms of each of these peptides (Fricker, 2010).

After secretion, peptides undergo additional proteolytic processing by endo- and exo-peptidases, all of which are relatively nonselective and cleave a large variety of neuropeptides. The major enzymes known to cleave opioid peptides at this stage include neprilysin, angiotensin-converting enzyme, and aminopeptidase $\mathrm{N}$, but other enzymes may also contribute (e.g., endothelin-converting enzymes 1 and 2) (Fricker, 2012). Although inhibitors of neprilysin were originally developed as potential analgesics, they did not prove efficacious for this indication. Instead, neprilysin inhibitors treat diarrhea (racecadotril) and heart failure (sacubitril). Though treatment of diarrhea with racecadotril is thought to be mediated by increased levels of enkephalin in the intestine, the ability of sacubitril to treat heart failure is presumably due to inhibition of the degradation of vasoactive peptides such as bradykinin and not endogenous opioid peptides (Bayes-Genis et al., 2016).

A common feature of neuropeptides is that the extent of processing of the precursor into the mature peptides has an impact on the biologic properties of the resulting peptides (Fricker, 2012). There are many examples of this with opioid peptides, in which differently processed forms have altered affinities for the various opioid receptors (Mansour et al., 1995). For example, the peptide named BAM18, an 18-residue peptide that contains the N-terminal Met-enkephalin sequence, binds to all three opioid receptors, with slightly higher affinity for MOR and comparable affinity for KOR and DOR (Fig. 2). When this peptide is processed into metorphamide, the result is a substantial increase in potency toward all three receptors. Further processing to Met-enkephalin leads to slightly improved DOR binding but reduced MOR and KOR binding (Fig. 2). Even a single amino acid shortening can have an impact on the relative affinity of a peptide toward the three receptors. For example, $\alpha$ - and $\beta$-neoendorphin differ by a single C-terminal Lys residue. Conversion of $\alpha$-neoendorphin into $\beta$-neoendorphin by removal of the Lys residue causes a 4 - to 5 fold decrease in potency toward MOR and KOR but no change in potency toward DOR (Fig. 2). If this peptide was further cleaved into Leu-enkephalin, the result would be a dramatic decrease in potency toward KOR and smaller changes in binding affinity toward the other receptors (Fig. 2). However, it is not clear if this latter cleavage occurs in vivo because most of the Leu-enkephalin in brain is likely to come from PENK, not PDYN (this is discussed in more detail in the section on "Future Directions").

\section{Distribution}

The tissue distribution of endogenous opioid peptides and their receptors provides clues as to their physiologic function. This section is divided into three parts. First, we discuss the distribution of the mRNAs that encode the peptide precursors, focusing on large-scale studies that compared multiple genes and tissues. Second, we briefly summarize the distribution of key opioid peptides and discuss similarities and discrepancies 


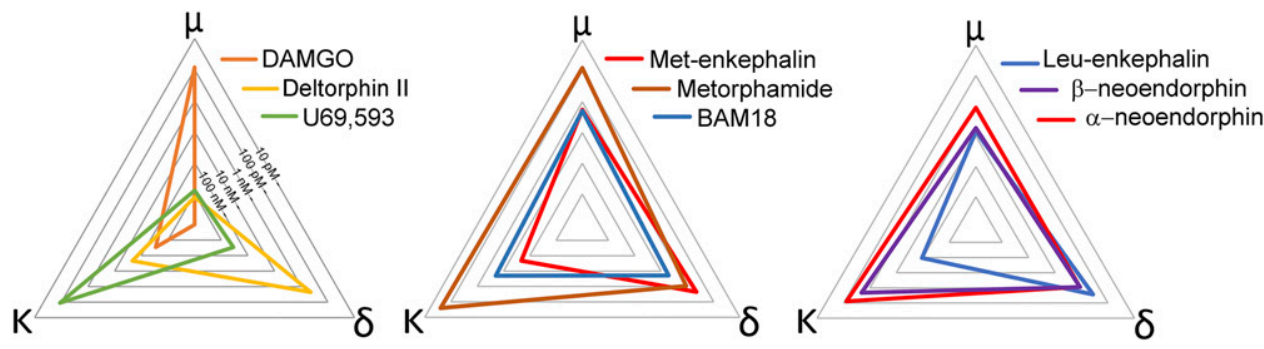

Fig. 2. Binding affinities of representative opioid peptides for the $\mu(\mathrm{MOR}), \delta(\mathrm{DOR})$, and $\kappa$ (KOR) opioid receptors. Binding affinity data of representative peptides from Mansour et al. (1995) were plotted on radar charts (middle and right panels). In brief, Mansour et al. transfected COS-1 cells with cDNA expressing the three opioid receptors. Binding assays used the tritiated ligands DAMGO, [D-Pen ${ }^{2}, \mathrm{D}-\mathrm{Pen}^{5}$ ]-enkephalin, and U69,593 for MOR, DOR, and KOR, respectively, and competition studies used a minimum of 12 concentrations of the indicated peptide to determine its Ki value for each receptor. These graphs use a log scale in which the outer triangle represents a Ki of $10 \mathrm{pM}$, and each inner triangle represents 10 -fold higher Ki (scale is shown on the left panel), with the innermost triangle representing $1 \mu \mathrm{M}$. Thus, ligands that bind most potently to the three receptors occupy a larger space than ligands that bind with weaker affinity. In addition, those ligands that are selective for one receptor show narrow triangles. This is illustrated by the three standards shown in the left panel: DAMGO, Deltorphin II (DeltII), and U69,593. Because the Mansour et al. (1995) paper did not report the affinity of selective synthetic ligands for each of the three receptors, the data for the left panel were obtained from a similar radioligand binding study, using tritiated diprenorphine as the radioligand and 12-15 concentrations of the indicated compound to determine its Ki value for each receptor (Gomes et al., 2020). The middle panel compares BAM18, metorphamide, and Met-enkephalin, three peptides that represent different cleavage forms of the same region of the precursor (see Fig. 1). The right panel compares two highly related peptides, $\alpha$-and $\beta$-neoendorphin, representing the difference of a single residue on the C-terminus. In addition, Leu-enkephalin is included in this panel, although it is not clear if either $\alpha$ - or $\beta$-neoendorphin is processed into Leu-enkephalin.

with the distribution of mRNA encoding the peptides. Finally, we briefly describe the results of studies comparing the distribution of opioid peptides and receptors.

Distribution of mRNAs that Encode the Opioid Peptide Precursors. Many researchers have investigated the distribution of mRNA encoding the opioid peptide precursors, but most of the published studies examined specific tissues of interest, focusing mainly on brain regions and a few other tissues. To provide a comprehensive overview, we compiled data from various "big data" sources that investigated thousands of genes. One database we used was The Human Protein Atlas, which includes 62 tissues or subregions of these tissues (e.g., 11 brain regions) (Uhlén et al., 2015). We also used a large-scale microarray study that examined $\sim 50$ regions of mouse brain and related tissues (e.g., spinal cord, pineal gland, pituitary, retina) (Kasukawa et al., 2011). These data are summarized in Supplemental Table 1. Although mRNAs encoding all three opioid peptide precursors are expressed at high levels in some brain regions, they are not exclusively present in the brain. For example, in human tissues, PENK mRNA is most highly expressed in basal ganglia, and the next highest level of expression is the adrenal gland followed by testis. Nonbrain tissues such as cervix/uterus, prostate, ovary, and heart are also in the top 10 for PENK mRNA expression. PDYN mRNA expression is also highest in the basal ganglia and enriched in testis (Supplemental Table 1). POMC mRNA expression is extremely high in the pituitary, with the next highest expression levels in pancreas and cells of the immune system. Data for opioid receptor mRNA, PNOC mRNA, and mRNA for key biosynthetic and extracellular peptidases are also included in Supplemental Table 1. As with the distributions of PENK and PDYN mRNA, the genes for the various receptors and enzymes are highly expressed in some brain regions as well as many additional tissues, including cells of the immune system and reproductive system. The distributions of the mRNAs encoding the opioid peptide precursors and the opioid receptors suggest that this system participates in a variety of physiologic functions beyond the central nervous system-mediated effects that have been the overwhelming focus of research.
Distribution of Opioid Peptides and the Precursor mRNAs. Many studies have examined the opioid peptide content across brain regions and other tissues, with most of the early studies using radioimmunoassays to detect the peptides. Often, the level of an opioid peptide in a brain region or tissue is proportional to the level of the mRNA that encodes the peptide precursor. However, some exceptions have been reported, especially in peripheral tissues that have high expression of precursor mRNAs but low or undetectable levels of peptides derived from these precursors. These exceptions include PENK mRNA in rat heart and mRNA encoding all three opioid peptide precursors in the testis (Schafer et al., 1991). Potentially contributing to some of these mismatches are differences in the sizes of mRNA. Testis PENK mRNA is 350 bases longer than in brain (Schafer et al., 1991), and testis POMC mRNA is 2400 bases shorter than in the pituitary (Garrett and Douglass 1989). The shorter testis POMC mRNA lacks the exon containing the signal peptide, which means that the resulting shorter protein is produced in the cytosol where it cannot be processed into the mature bioactive peptides. In cases in which the mRNA encodes the full-length precursor, the mismatch between relatively high mRNA levels and low or undetectable peptide levels can potentially be due to inefficient translation or degradation of the precursor proteins and/or the peptides. These factors would reduce the amount of biologically active peptides produced in the tissue.

Alternatively, it is possible that tissues with high levels of mRNA for the opioid peptide precursors are major sources of the secreted protein and/or peptides despite low tissue levels. For example, opioid peptides have been detected in testicular interstitial fluid at levels several-fold higher than in plasma, presumably reflecting secretion from cells in the testis that produce but do not store high levels of the protein/peptide (Valenca and Negro-Vilar, 1986). The cells in rat heart and testis with the highest amounts of PENK mRNA lack the typical storage secretory granules found in neuroendocrine secretory tissues (Schafer et al., 1991). This has two consequences: first, the proteolytic processing of the precursor will be limited by the lack of an appropriate environment for the 
enzymes to function. Because many radioimmunoassays specifically detect the cleaved peptides, these assays will underreport the level of precursors that are produced in these tissues. Second, without secretory vesicles to store the precursors and/or partially processed peptides, they will be secreted soon after biosynthesis. If these larger peptides are biologically active, then the tissues that have high mRNA levels of the precursors can potentially produce substantial amounts of protein/peptide in circulation. Thus, the levels of opioid peptides in peripheral tissues that lack peptide storage vesicles typical of neuroendocrine cells is not necessarily reflective of the overall production and secretion of bioactive peptides.

Individual opioid peptides often show regional variations that are distinct from other peptides produced from the same precursor protein. For example, the major opioid peptide detected in the anterior lobe of the pituitary is $\beta$-endorphin . $_{1}$ ${ }_{31}$; this peptide is further processed into $\mathrm{N}$-acetyl- $\beta$-endorphin ${ }_{1-}$ ${ }_{27}$ in the intermediate lobe because of the presence of additional enzymes (Schafer et al., 1991). In the case of PENK-derived peptides, the levels of metorphamide in bovine pituitary neurointermediate lobe, brain (caudate and hypothalamus), and spinal cord are much lower than the levels of octapeptide (Tyr-Gly-Gly-Phe-Met-Arg-Gly-Leu) or heptapeptide (TyrGly-Gly-Phe-Met-Arg-Gly) (Sonders and Weber 1987). Conversely, in the rat olfactory bulb, metorphamide levels are high but octapeptide is undetectable, suggesting either inefficient processing of metorphamide to shorter peptides or rapid degradation of octapeptide (Miyata et al., 1984). Variations in the levels of PDYN-derived peptides have also been noted. For example, levels of dynorphin $\mathrm{A}_{1-17}$ and dynorphin $\mathrm{A}_{1-8}$ are similar in the pituitary, whereas dynorphin $\mathrm{A}_{1-8}$ is the predominant peptide in many brain regions, although the ratio of dynorphin $\mathrm{A}_{1-8}$ to dynorphin $\mathrm{A}_{1-17}$ varies across brain regions (Weber et al., 1982; Cone et al., 1983; Seizinger et al., 1984; Hollt, 1986). Levels of $\alpha$ - and $\beta$-neoendorphin are similar in posterior pituitary, whereas $\alpha$-neoendorphin levels are generally higher than $\beta$-neoendorphin in brain, and the ratio of the two forms is variable among different regions (Seizinger et al., 1984; Hollt, 1986). Because the conversion of $\alpha$-neoendorphin into $\beta$-neoendorphin is a slow reaction catalyzed by carboxypeptidase $\mathrm{E}$, these observations could be due to variations in the levels of carboxypeptidase $\mathrm{E}$ or in the average age of the secretory granules in the different cell types. Other factors may also influence enzymatic activity, including competition from other substrate peptides or $\mathrm{pH}$ (Greene et al., 1992). In summary, the ratio of the long/short forms of endogenous opioid peptides varies across tissues and presumably varies within individual cell types within brain regions, as the ratio is ultimately dependent on the expression and availability of the various processing enzymes and/or the age of the secretory vesicles (Cone et al., 1983).

Correlation between the Distribution of Opioid Peptides and Receptors. A number of techniques have been used to study the distribution of opioid receptor expression, including immunocytochemistry, radioligand binding, positron emission tomography, and transgenic mice expressing tagged receptors (McLean et al., 1987; Arvidsson et al., 1995; Svingos et al., 1995; Le Merrer et al., 2009; Erbs et al., 2015; Cumming et al., 2019). One study used values reported in the literature to compare the brain distribution of 1) opioid receptor protein using ligand autoradiography; 2) opioid receptor mRNA in cell bodies using in situ hybridization data; 3) opioid peptide precursors using immunohistochemistry; and 4) opioid peptide precursors in the cell bodies using immunohistochemical and in situ hybridization (Le Merrer et al., 2009). Though many of the studies revealed generally overlapping patterns of receptor and peptide expression, several exceptions were noted (McLean et al., 1987; Arvidsson et al., 1995; Le Merrer et al., 2009). For example, in some brain regions, KOR expression parallels the expression of PENKderived peptides and not PDYN-derived peptides (Arvidsson et al., 1995; Le Merrer et al., 2009). Hence, in these regions, KOR could be activated by PENK-derived peptides rather than PDYN-derived peptides. The overlapping affinities of the various opioid peptides toward the three opioid receptors (Fig. 2), the ability of these peptides to elicit signaling at the three opioid receptors (Fig. 3), and the broad distribution of these molecules support the idea that endogenous opioid peptides derived from all three precursors can physiologically activate each of the opioid receptors in some tissues or brain regions.

\section{Function of Opioid Peptides}

Based on the broad distribution of the opioid peptides, it is likely that each peptide performs a wide variety of overlapping functions. Though some functions have been identified and are described below, it is difficult to fully investigate the behavioral roles of endogenous opioids because of limitations of current techniques. These techniques fall into three broad categories: 1) adding peptides to an organism by microinjection or other approaches and looking at the impact on physiology/behavior; 2) eliminating peptide signaling by using receptor antagonists or gene knockout approaches and observing the physiologic/behavioral changes; and 3) measuring the release of endogenous peptides under various physiologic states. Each of these approaches is described below, along with caveats that limit the interpretation of the results.

Studies Testing the Consequences of Adding Peptides. Bioassays testing the effect of added peptides have provided essential information, starting with the initial discovery of the enkephalins in the 1970s. This discovery used a functional assay involving electrically evoked contractions of dissected guinea pig ileum or mouse vas deferens, which were previously shown to be slowed by the addition of opiates, and the opiate effect was reversed by naloxone (Schaumann, 1955; Henderson et al., 1972). Brain extracts were able to mimic the effect of opiates, and after purification and sequencing, Metand Leu-enkephalin were identified (Hughes et al., 1975). The differential sensitivity of the guinea pig ileum versus the mouse vas deferens assays to various chemical species contributed to the hypothesis that there were multiple opioid receptors (Lord et al., 1977). These and other assays led to the conclusion that although there is some preferential binding/ activity of the different endogenous opioid peptides for the three opioid receptors, overall, none of the endogenous peptides is highly selective for any of the receptors (Kosterlitz, 1985).

Soon after the endogenous opioid peptides were identified, studies were conducted to investigate their function in animal models. Central administration of various opioid peptides produces antinociception (Belluzzi et al., 1976; Buscher et al., 1976) and rewarding effects in self-administration and place conditioning paradigms (Belluzzi and Stein, 1977; Phillips 


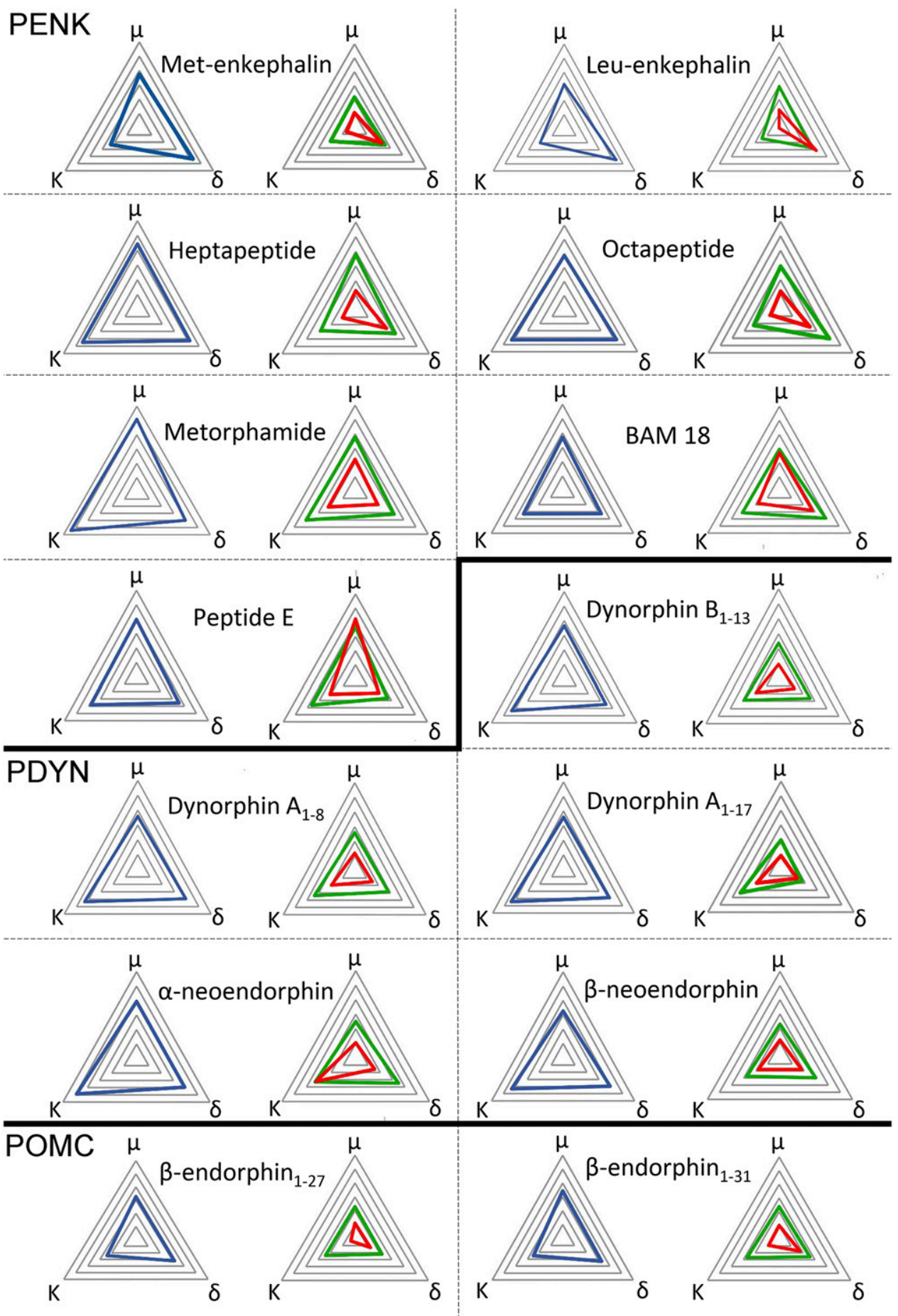

Fig. 3. Summary of the major opioid peptides' affinity for the various opioid receptors. For each peptide, two radar graphs are shown; both use the same scale as Fig. 2. The graphs on the left with blue lines represent data from Mansour et al. (1995). The graphs on the right show signaling through $\mathrm{G}$ proteins (green) and $\beta$-arrestin (red), using data from the supplementary tables of Gomes et al. (2020). Assays were carried out using cells (for $\beta$-arrestin recruitment) or membranes of cells (for GTP $\gamma \mathrm{S}$ binding) expressing $\mu, \delta$, or $\kappa$ opioid receptors that were C-terminally tagged with a ProLink/ $\beta$-gal donor (PK) fragment and $\beta$-arrestin 2 tagged with a complementary $\beta$-gal activator (EA) fragment as described (Gomes et al., 2020). $\beta$-arrestin recruitment and GTP $\gamma \mathrm{S}$ binding were conducted as described (Gomes et al., 2013).

et al., 1983). Opioid peptides also promote reward and food consumption (Kastin et al., 1976; McKay et al., 1981). Opioid peptide function has been intensely studied within the midbrain dopamine system, supporting a role in reward and reinforcement signaling. For instance, microinjection of $\left[\mathrm{D}-\mathrm{Ala}^{2}\right]-M e t-e n k e p h a l i n$ into the ventral tegmental area increases food consumption and operant responding for delivery of food pellets (Cador et al., 1986; Kelley et al., 1989).

Although these studies provide valuable information on potential functions of the peptide, there are several shortcomings to the approach of microinjecting synthetic peptides into brain. First, the concentrations of injected peptides are usually much higher than expected under endogenous conditions. Second, there is far less spatial and temporal regulation of the exogenously applied peptide compared with endogenously secreted peptides. Furthermore, the applied peptides (like their endogenous counterparts) are unstable and are cleaved into shorter forms that usually have distinct activities from the administered peptide, leading to complications in the interpretation of the data. For these reasons, 
studies testing exogenous peptides are important but may not accurately reflect the normal function of the endogenously released peptides.

Because the endogenous peptides are unstable and can be broken down, stabilized forms of the peptides have been used in many animal studies. However, such modifications often alter the relative affinities of the peptides at the opioid receptors. For instance, [D-Ala ${ }^{2}, \mathrm{~N}-\mathrm{MePhe}^{4}$, Gly-ol]-enkephalin (DAMGO) is a modified enkephalin molecule that is very stable in ex vivo and in vivo conditions, but unlike enkephalin, it is very selective for MOR (Handa et al., 1981). Peptides from frog skin (deltorphins) were found to be highly selective for DOR; these peptides contain either a D-Ala or D-Met in the second position, which enhances their stability. Another DORselective compound commonly used in animal studies is the synthetic peptide [D-Pen $\left.{ }^{2}, \mathrm{D}-\mathrm{Pen}^{5}\right]$-enkephalin (Mosberg et al., 1983). Although such stabilized peptides have been used to probe the physiologic and behavioral effects of the different opioid receptor systems to great success, it should be noted that given their altered biochemistry and specificity, they are not true proxies for the endogenous peptides (King et al., 1979).

To avoid some of the problems inherent to studies involving microinjection of synthetic peptides, optogenetic techniques have recently been used to selectively stimulate neurons that express opioid peptides (Al-Hasani et al., 2015; Parker et al., 2019). Driving the release of endogenous peptides has several advantages over microinjection of synthetic peptides. However, because neurons typically express a number of different neurotransmitters and neuropeptides, many of which are presumably coreleased upon optogenetic stimulation, the interpretation of the results is complicated. The use of specific receptor antagonists together with optogenetic approaches can identify the receptor involved and thus provide more information.

An alternative strategy to investigate peptide function is to block the peptidases that break down the endogenous opioid peptides. This approach is intended to elevate extracellular concentrations of peptides that are released by normal behavioral stimuli and prolong their lifetime, thus preserving the spatial/temporal signaling of the endogenous peptides. For instance, microinjection of the neprilysin inhibitor, thiorphan, into the ventral tegmental area is rewarding, producing conditioned place preference (Glimcher et al., 1984). However, because the peptidases that degrade the endogenous opioid peptides also break down many nonopioid peptides in brain, blocking these enzymes does not necessarily result in a behavior driven exclusively by the opioid system.

Studies Testing the Consequences of Blocking Peptide Signaling. A completely different approach to explore the function of endogenous opioid peptides is to determine the consequences of reduction or elimination of the signal. One way to accomplish this is with antagonists that block a specific receptor, ideally using antagonists that are highly selective and devoid of partial or inverse agonist properties. Early studies used naloxone, an antagonist with greatest potency at MOR, slightly lower potency at DOR, and weaker binding to KOR. The administration of naloxone was able to reverse the analgesic effect that was induced by electroacupuncture, both in animal and in human studies (Pomeranz and Chiu 1976; Ulett et al., 1998). Analgesia induced by placebo treatments also appears to be mediated in part by the endogenous opioid peptides, with postoperative pain scores elevated by naloxone specifically in individuals who demonstrated placebo analgesia (Levine et al., 1978, 1979). Placebo antinociception in experimentally induced pain is also reversed by naloxone (Benedetti, 1996). However, in the absence of the expectation of pain relief or antinociception, naloxone does not generate hyperalgesia (ter Riet et al., 1998). Taken together, these studies suggest a link between placebo-induced analgesia and endogenous opioid peptide release but do not support a major role for endogenous opioid peptides in setting baseline pain sensitivity.

Animal studies with antagonists have further enabled the study of behavioral states in which endogenous opioids may be released and drive changes in neural circuit activity and behavioral responses. For example, the role of the endogenous opioid system on physiologic and behavioral responses to stressors has been investigated with opioid antagonists. Endogenous opioids appear to drive dopamine release in the prefrontal cortex in response to an aversive stressor based on the finding that naloxone prevented stressor-induced dopamine release (Miller et al., 1984). In this study, stress did not drive dopamine release in the nucleus accumbens or caudate nucleus (Miller et al., 1984). Other studies using selective KOR antagonists also found evidence that endogenous opioid peptides contribute to the encoding of aversive experiences (McLaughlin et al., 2006; Land et al., 2008; Chavkin, 2018; Robble et al., 2020).

The contribution of endogenous opioid peptides to the motivational qualities of ethanol has been well established. Selective opioid receptor antagonists alter ethanol consumption in many animal models (Margolis et al., 2008; Walker and Koob, 2008), and the nonselective opioid receptor antagonist naltrexone is a Food and Drug Administration-approved treatment for alcohol use disorder (Klemperer et al., 2018; Kranzler and Soyka, 2018). It is thought that opioid antagonism works in people by decreasing the positive reinforcement experienced from the alcohol consumption (Myrick et al., 2008; Lukas et al., 2013; Schacht et al., 2017). Animal studies also implicate endogenous opioids in the rewarding effects of other drugs of abuse, including cocaine and amphetamine, as naltrexone administration that is not aversive on its own blocked conditioned place preference to these drugs (Trujillo et al., 1991; Gerrits et al., 1995; Biała and Langwiński, 1996; Windisch et al., 2018).

Though these studies provide important information, it is unclear if the antagonists block ongoing actions of the peptides under baseline conditions or the actions of those released specifically in response to a particular behavioral stimulus. These studies also do not provide information regarding which peptides are released, only the target receptor whose activity is blocked. Finally, under some circumstances such as heterodimerization, an antagonist at one receptor may augment binding or signaling at a different receptor (Gomes et al., 2000, 2004,2011 ), raising the possibility that the antagonist could function as a positive allosteric modulator in the relevant circuit.

Function can also be explored by using genetic approaches to eliminate the expression of opioid peptides (i.e., "knockout" mice) or to express tools such as optogenetic channels to reduce the neuronal firing that drives the secretion of peptides. Behaviors that are impaired or altered in knockout mice in which the peptide precursor molecules are deleted are highly 
suggestive of the endogenous opioid peptide functions. These studies usually do not provide information about the function of individual peptides, but only on the collective function of all peptides produced from the precursor that is eliminated, or from the portion of the precursor that was deleted. For example, $\beta$-endorphin was selectively deleted from the POMC gene by the introduction of a stop codon preceding this peptide, thereby preserving the production of the nonopioid peptides, and the resulting mouse line shows an interesting phenotype (described below). However, it is not clear if the observed behavioral changes are due to the loss of $\beta$-endorphin ${ }_{1-31}$ or one of the other forms (e.g., $\beta$-endorphin ${ }_{1-27}, \beta$-endorphin ${ }_{1-26}$, acetylated $\beta$-endorphin peptides, or shorter forms such as $\alpha$ and $\gamma$-endorphin) (Rubinstein et al., 1996). Another caveat with genetic approaches is that compensatory changes may obscure the peptides' function or even falsely implicate the system; this is a complication of all genetically modified animal strains, especially with nonconditional knockout animals.

Mice with a truncation of POMC that eliminates production of the $\beta$-endorphin peptides are generally normal in their response to the antinociceptive effects of systemic morphine (Rubinstein et al., 1996; Mogil et al., 2000). One study reported that these mice do not develop analgesia in response to a mild swim stress (Rubinstein et al., 1996; Mogil et al., 2000), but another study reported stress-induced analgesia in these mice (Rubinstein et al., 1996; Mogil et al., 2000). Mice lacking $\beta$-endorphin also show a paradoxical naloxone-induced analgesia, suggesting compensatory upregulation of alternative pathways (Rubinstein et al., 1996). These mice also exhibit an increase in oral ethanol self-administration (Grisel et al., 1999) and gain more weight on a high-fat diet than wild-type mice (Appleyard et al., 2003). Dual knockouts of PENK and POMC show diminished reward from ethanol in the placeconditioning model (Tseng et al., 2013). However, ethanol consumption and the motivational drive to consume ethanol are not affected in double knockout mice, raising the possibility that the opioid peptides specifically play a role in reinforcement learning (Hayward et al., 2004). Genetic deletion of PDYN increases ethanol place conditioning, raising the possibility that the dynorphin system limits the rewarding effects of ethanol (Nguyen et al., 2012). These observations are consistent with a general proposition that MOR and KOR systems function in opposition in many brain regions and behavioral conditions (Shippenberg et al., 1992; Pan et al., 1997). Genetic deletion of PDYN also diminishes responses to aversive stressors in mice (McLaughlin et al., 2003), most likely by decreasing activation of the KOR system (Bruchas et al., 2007); such an idea is supported by studies using KOR antagonists (Xie et al., 2017; Navratilova et al., 2019; Page et al., 2019). Taken together, studies of mice lacking opioid peptide precursors have been informative, although some are difficult to interpret in light of the seeming incongruencies with observations from other techniques.

Studies Examining Release of Endogenous Opioid Peptides. Another approach to explore the function of cellcell signaling molecules is to determine when the molecules are released into the synapse. For aminergic modulators such as dopamine, it is relatively easy to measure release from neurons using microdialysis or electrochemical approaches. However, these techniques are much more difficult to apply to neuropeptides because of their low abundance, instability, and tendency to stick to plastic tubing. Recent improvements in microdialysis sample analysis have enabled peptide detection; however, sampling intervals remain long (20 minutes) to accumulate sufficient peptide for detection (DiFeliceantonio et al., 2012; Al-Hasani et al., 2018). With this approach, increases in enkephalin, but not dynorphin, release were observed in the dorsomedial striatum when rats consumed chocolate (DiFeliceantonio et al., 2012). Alternative approaches that use electrochemistry are promising for improving sampling rates to subsecond resolution, and the small carbon fiber electrodes used in this approach generate little to no gliosis, enabling detection much closer to release sites than possible with microdialysis probes (Schmidt et al., 2014; Calhoun et al., 2019). This approach has been used to detect Met-enkephalin release in rats in the dorsomedial striatum concurrent with consumption of a sweet palatable food (Calhoun et al., 2019). One drawback to electrochemistry is that accurate identification of a specific peptide is less certain compared with postmicrodialysis sample processing, and though the electrochemical waveform of Met-enkephalin can be distinguished from Leu-enkephalin, it is possible that other peptides that contain both Tyr and Met (e.g., metorphamide) could contribute to the Met-enkephalin signal (Calhoun et al., 2019).

An indirect approach to detect the release of endogenous peptides is to use positron-emission tomography (PET) to measure changes in receptor occupancy; this has been used to study the endogenous opioid system in humans and rodents (Schmitt et al., 2017). PET studies in humans demonstrated that acute alcohol consumption decreases binding of $\left[{ }^{11} \mathrm{C}\right]$ carfentanil in various brain regions, including the ventral striatum and orbital frontal cortex, suggesting endogenous opioid peptides are released in response to alcohol drinking (Mitchell et al., 2013). PET studies also support the proposal that endogenous opioid peptide binding to KOR increases in response to cocaine (in cocaine use disorder subjects), especially in the striatum (Martinez et al., 2019). Because it is a receptor-based technique, PET studies do not provide information on the specific opioid peptides that are released but only the general involvement of endogenous opioid peptides that bind to the receptor, which is targeted by the radiolabeled ligand.

\section{Myths, Mysteries, and Future Directions}

Much has been learned in the past five decades of research on opioid peptides, but several myths persist. Many of these myths are logical hypotheses that were subsequently found to be incorrect, but the ideas have persisted in spite of the evidence. One very common error made in the popular press is the use of the term "endorphins" to refer to all endogenous opioid peptides and not specifically to the molecules named endorphin (e.g., $\beta$-endorphin - $_{1-31}$ and shorter forms). When sports writers refer to endorphins causing runner's high, they really mean opioid peptides in general and may also be referring to sensations generated by other rewarding endogenous molecules such as endocannabinoids. The persistence of the term "endorphin" in the lay press is likely due to its catchy name, derived from a contraction of endogenous morphine.

Other common myths and misconceptions regarding the opioid peptides are described below. In addition, we describe some major unanswered questions in the field and areas in need of further research. 
Specificity and Selectivity of the Peptides, Receptors, and Enzymes. One misconception concerns the selectivity of the various components of the opioid system. In the early days of the field, there were initial reports that enzymes were specific for enkephalins, either their biosynthesis (i.e., "enkephalin convertase") (Fricker and Snyder, 1982) or degradation (i.e., "enkephalinase") (Malfroy et al., 1978). The enzymes described in these early reports are still implicated in the production and degradation of the enkephalins, but it is now clear that neither enzyme is specific. Enkephalin convertase was renamed carboxypeptidase $\mathrm{E}$ because it is responsible for the biosynthesis of the vast majority of neuropeptides and peptide hormones (Fricker, 2018). Enkephalinase, now known as neprilysin, cleaves a large number of biologically active peptides (Bayes-Genis et al., 2016). Despite this, there are dozens of recent papers that use the name "enkephalinase" in the title, giving the false impression that this enzyme is selective for the degradation of enkephalin.

A related misconception concerns the selectivity of individual peptides for MOR, DOR, and KOR. Because there are three precursor proteins and three opioid receptors, or four if nociceptin and its receptor are included, scientists hypothesized that each precursor generated products that were highly selective for one of the receptors. Though this is true for nociceptin and its receptor, it is not the case for the other three. Although the major dynorphin peptides bind with highest affinity to KOR, they also bind with high affinity to MOR and DOR (Fig. 3). Similarly, it is an oversimplification to state that POMC-derived $\beta$-endorphin ${ }_{1-31}$ binds to MOR whereas the enkephalins bind to DOR. Based on the binding and activity properties of the various peptides, it is clear that the system is much more complex than "one ligand one receptor," with a number of different endogenous opioid peptides serving as ligands for each of the three opioid receptors (Fig. 3).

The Diversity of Peptide Products. A common oversimplification is that PENK makes enkephalin, PDYN makes dynorphin, and POMC makes $\beta$-endorphin (in addition to ACTH and $\alpha$-MSH). Rather than a simple precursor/product relationship, many of the opioid peptides exist in multiple active forms depending on the degree of proteolytic processing or other post-translational processing events (Fig. 1), and these forms have different affinities for each of the receptors (Figs. 2 and 3).

The earliest evidence supporting the processing of PENK into multiple bioactive peptides came from studies examining relative levels of each peptide. For example, the seven residue "heptapeptide" is present in brain at one-fifth the level of Met-enkephalin, and because there are ultimately six copies of Met-enkephalin within PENK (Fig. 1), this implies that the heptapeptide is not efficiently converted into Met-enkephalin (Stern et al., 1979). Although the level of Leu-enkephalin is higher than the various dynorphin peptides in most brain regions, which was initially interpreted to mean that dynorphin is converted into Leu-enkephalin, this assumption ignores the contribution from PENK, which contains 1 copy of Leu-enkephalin flanked by consensus sites for the processing enzymes (Fig. 1). Because the level of Leu-enkephalin is typically similar to the level of heptapeptide in most brain regions (Hughes et al., 1977; Stern et al., 1979), the amount of Leu-enkephalin in brain is consistent with the complete conversion of PENK into Leu-enkephalin without any conversion of the dynorphin peptides into Leu-enkephalin. Although it is possible that some of these dynorphin peptides are processed into the pentapeptide, peptidomic analysis of mouse brain has failed to find evidence of this (e.g., fragments such as Dynorphin $\mathrm{A}_{8-17}$ are not detected). In contrast, peptidomic analyses of fragments produced from PENK found evidence that BAM18 is processed into metorphamide and Met-enkephalin based on the detection of PENK fragments 221-28 and 218-28, respectively (Fig. 1).

The Regulation of Peptide Processing. The extent of processing of the precursors into various products is not the same in all tissues or cell types, which increases the complexity of the system. Furthermore, the extent of processing can also vary within the same cell type under different conditions. The endopeptidases prohormone convertases 1 and 2 have distinct substrate specificities and efficiencies toward the cleavage sites within the precursors, and the presence/absence of these enzymes in different cell types greatly alters the products. The age of the secretory granules is also a factor in the extent of processing of the precursor, with younger granules containing larger peptides compared with the older granules. As a side point, studies on a variety of other neuroendocrine cell types have shown that peptides stored in younger granules are preferentially secreted under basal conditions, whereas older granules preferentially release their peptide content upon stimulation (Sando et al., 1972; Gold et al., 1982; Noel and Mains, 1991; Duncan et al., 2003; Che et al., 2004). It is therefore possible that the extent of neuronal stimulation will affect the forms of peptides that are released, and this is an area for further research.

Another factor affecting the forms of opioid peptides produced within a cell is the presence of catecholamines. Treatment of cells with reserpine, which reduces the level of catecholamines within secretory granules, increases the levels of enkephalin and other opioid peptides (Wilson et al., 1980; Eiden et al., 1984; Eiden and Zamir, 1986; Lindberg, 1986). Subsequently, it was found that catecholamines function as competitive inhibitors of the prohormone convertases and carboxypeptidase E (Helwig et al., 2011). Thus, intracellular processing of opioid peptide precursors is a dynamic process that can be regulated by a variety of factors.

In addition to the variability of processing prior to secretion, there is even more complexity following secretion. A plethora of extracellular peptidases cleave opioid peptides and produce a large number of products, some of which retain receptorbinding properties. The cleavage of opioid peptides by extracellular peptidases is an area in need of additional studies; this is a difficult topic to pursue because of the transient nature of the secreted peptides and overlapping specificity of many of the peptidases.

Endocytic Processing. Another common misconception relates to events that follow peptide binding to a receptor. It is generally thought that once receptors are internalized, even if the peptide remains bound to the receptor, the concentration of the peptide in the endocytic compartment will be too low to signal. The reasoning is that if a stoichiometric amount of peptide and receptor were internalized, there would only be one peptide molecule in an endocytic vesicle containing one receptor molecule. However, a single molecule of peptide in a small endocytic vesicle is calculated to be in the nanomolar range, depending on the size of the endocytic compartment, and this level is sufficient to stimulate the receptor as it moves 
through the endocytic pathways. Peptidases such as endothelinconverting enzyme 2 are present in endocytic compartments where they can potentially cleave the peptide, thereby altering the ligand (Gupta et al., 2014, 2015). Several recent studies found that inhibition of endothelin-converting enzyme 2 affected opioid receptor signaling and trafficking (Gupta et al., 2014, 2015). Further studies are needed to explore the role of endocytic processing events and their impact on receptor function.

Functions of Individual Opioid Peptides. When a PENK-expressing neuron is stimulated, the cell releases multiple peptides containing the Met- and Leu-enkephalin sequences as well as other peptides processed from the precursors (discussed in the next subsection). Similarly, PDYN- and POMC-expressing neurons also release multiple peptides. A mystery in the field has been the biologic function of all the different endogenous opioid peptides.

Because each opioid peptide has a different affinity for MOR, DOR, and KOR (Figs. 2 and 3), these peptides will likely have distinct biologic activities. Furthermore, it is possible that each opioid peptide stabilizes different conformations of the opioid receptors that activate distinct signaling cascades. A study examining signaling pathways activated by a panel of opioid peptides at MORs found that some peptides exhibited differences in functional selectivity compared with the standard, DAMGO (Thompson et al., 2015). This raises several questions: 1) Are the signaling cascades activated by individual opioid peptides the same for all three opioid receptors? 2) What are the spatiotemporal dynamics of this signaling? 3) Do these peptides exhibit biased signaling? Recent studies have begun to explore the intricacies of endogenous opioid peptide signaling at the different opioid receptors. One recent study tested 20 opioid peptides derived from the three precursors and found that each peptide was able to activate $\mathrm{G}$ protein signaling by all three opioid receptors, albeit with different potencies (Gomes et al., 2020). However, there was much greater variability in the recruitment of $\beta$-arrestin and hence a wide range of biased signaling (Gomes et al., 2020). The preference of 14 representative opioid peptides to signal through $\mathrm{G}$ proteins versus $\beta$-arrestin is shown in Fig. 3.

The idea that different forms of an opioid peptide produce divergent biologic effects was first reported for $\beta$-endorphin, but these initial findings have not been confirmed using other approaches. The original studies reported that the unacety-

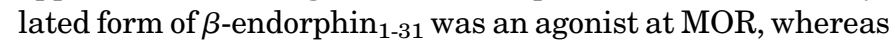
the shorter $\beta$-endorphin ${ }_{1-27}$ was an antagonist and $\beta$-endorphin -en $_{1-26}$ was inactive (i.e., neither an agonist nor antagonist) (Hammonds et al., 1984; Nicolas and Li, 1985). At the time, this was considered an excellent example in which the degree of enzymatic processing altered the biologic activity, but these conclusions were based on indirect studies involving administering peptides to animals. Subsequent studies in animals (Hirsch and Millington, 1991) and in vitro (Alt et al., 1998) found that $\beta$-endorphin - $_{1-27}$ is a full agonist at MORs with similar potency to $\beta$-endorphin ${ }_{1-31}$. This has recently been confirmed and extended by measuring signaling through $G$ protein and $\beta$-arrestin pathways in cell culture as well as synaptic physiology in acute brain slices, with the finding that $\beta$-endorphin ${ }_{1-26}$ and $\beta$-endorphin 1-27 are full agonists with potencies similar to

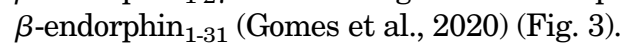

Potential Functions of the Nonopioid Peptides. It is generally assumed that the nonopioid portions of the precursors that lack the enkephalin sequence (i.e. YGGFL/M) are devoid of biologic activity. Although peptides without this domain do not bind to MOR, DOR, or KOR, they may have other functions. Some of the nonopioid peptides generated from the precursors (Fig. 1) are highly conserved through evolution, suggesting possible functions. One potential function could be as ligands for nonopioid receptors. This concept is analogous to the POMC-derived peptides $\alpha$-MSH and ACTH, which bind to various melanocortin receptors. Alternatively, it is also possible that the 'inert' peptides co-secreted with the opioid peptides affect receptor activities by serving as competitors of extracellular peptidases. The secreted opioid peptides are not stable and are cleaved by peptidases located in the extracellular environment. Peptides that reduce the degradation of opioid peptides would therefore enhance opioid receptor activation. This is analogous to the reported opioidlike function of opiorphin and kyotorphin; these peptides do not directly bind to opioid receptors but instead prevent the degradation of endogenous opioid peptides. Within each of the precursors, there are numerous peptides that could serve as competitive inhibitors of neprilysin and the other extracellular peptidases, and further studies testing this possibility are needed.

A notable motif that is highly conserved among all precursors is the Cys residues located in the $\mathrm{N}$-terminal region (Supplemental Fig. 1). These Cys form intramolecular disulfide bridges, with three pairs of disulfides in PENK, PDYN, and PNOC and two pairs in POMC. Although this region has been proposed to be involved in the sorting of PENK into the regulated secretory pathway (Lecchi et al., 1997), other studies have shown that this region is not important for sorting (Albert and Liston 1993). Instead, it is possible that this region of PENK, PDYN, POMC, and PNOC functions after secretion from cells. The neuropeptides Agouti-related peptide (AgRP) and cocaine-and-amphetamine regulated transcript also contain Cys-rich domains with three to five disulfide pairs that are essential to their biologic function as neuropeptides. AgRP folds into a structure known as an inhibitor cystine knot, which is related to a structure found in invertebrate toxins that is stable and able to inhibit proteases (Yu and Millhauser, 2007). Though the spacing of Cys disulfide bonds in PENK, PDYN, and PNOC is very different from that of AgRP or cocaine-and-amphetamine regulated transcript, there is some similarity to other proteins that form "knottin" structures. Further studies are needed to test if the N-terminal Cys-rich regions of PENK, PDYN, and PNOC form actual knot-like structures (POMC, with only two pairs of disulfides, would not be capable of forming a knot-like structure). It is likely that this region serves an important function based on the high degree of conservation of the Cys residues and spacing as well as the presence of other residues in this $\mathrm{N}$-terminal region that are conserved between diverse species (Supplemental Fig. 1). Further studies are needed to explore this novel direction.

Roles of Opioid Peptides in Peripheral Tissues. Many studies have explored the functions of opioid peptides in peripheral tissues, but much less is known compared with the central functions. One exception is the intestine, where opioid peptides and their receptors play a role in gastrointestinal motility and the secretion of ions and fluid (Holzer, 2009). Much less is known about the role of opioid peptides in the immune system, the reproductive system, and other tissues 
that express high levels of the peptide precursors and the receptors (Supplemental Table 1). To fully understand the function of opioid peptides in all tissues in the body may take another five decades of research, if not longer, as this is a highly complex and intricate system.

\section{Authorship Contributions}

Wrote or contributed to the writing of the manuscript: All authors.

\section{References}

Akil H, Watson SJ, Young E, Lewis ME, Khachaturian H, and Walker JM (1984) Endogenous opioids: biology and function. Annu Rev Neurosci 7:223-255.

Albert PR and Liston D (1993) Deletions of the synenkephalin domain which do not alter cell-specific proteolytic processing or secretory targeting of human proenkephalin. J Neurochem 60:1325-1334.

Al-Hasani R, McCall JG, Shin G, Gomez AM, Schmitz GP, Bernardi JM, Pyo CO, Park SI, Marcinkiewcz CM, Crowley NA, et al. (2015) Distinct subpopulations of nucleus accumbens dynorphin neurons drive aversion and reward. Neuron 87: 1063-1077.

Al-Hasani R, Wong JT, Mabrouk OS, McCall JG, Schmitz GP, Porter-Stransky KA, Aragona BJ, Kennedy RT, and Bruchas MR (2018) In vivo detection of opticallyevoked opioid peptide release. eLife 7:e36520.

Alt A, Mansour A, Akil H, Medzihradsky F, Traynor JR, and Woods JH (1998) Stimulation of guanosine-5'-O-(3-[35S]thio)triphosphate binding by endogenous opioids acting at a cloned mu receptor. J Pharmacol Exp Ther 286:282-288.

Appleyard SM, Hayward M, Young JI, Butler AA, Cone RD, Rubinstein M, and Low MJ (2003) A role for the endogenous opioid beta-endorphin in energy homeostasis. Endocrinology 144:1753-1760.

Arvidsson U, Riedl M, Chakrabarti S, Vulchanova L, Lee JH, Nakano AH, Lin X, Loh HH, Law PY, Wessendorf MW, et al. (1995) The kappa-opioid receptor is primarily postsynaptic: combined immunohistochemical localization of the receptor and endogenous opioids. Proc Natl Acad Sci USA 92:5062-5066.

Bayes-Genis A, Barallat J, and Richards AM (2016) A test in context: neprilysin: function, inhibition, and biomarker. $J$ Am Coll Cardiol 68:639-653.

Belluzzi JD, Grant N, Garsky V, Sarantakis D, Wise CD, and Stein L (1976) Analgesia induced in vivo by central administration of enkephalin in rat. Nature $\mathbf{2 6 0}$ : $625-626$

Belluzzi JD and Stein L (1977) Enkephalin may mediate euphoria and drivereduction reward. Nature 266:556-558.

Benedetti F (1996) The opposite effects of the opiate antagonist naloxone and the cholecystokinin antagonist proglumide on placebo analgesia. Pain 64:535-543.

Biała G and Langwiński R (1996) Rewarding properties of some drugs studied by place preference conditioning. Pol J Pharmacol 48:425-430.

Bosler JS, Davies KP, and Neal-Perry GS (2014) Peptides in seminal fluid and their role in infertility: a potential role for opiorphin inhibition of neutral endopeptidase activity as a clinically relevant modulator of sperm motility: a review. Reprod $S c i$ 21:1334-1340.

Bruchas MR, Land BB, Aita M, Xu M, Barot SK, Li S, and Chavkin C (2007) Stressinduced p38 mitogen-activated protein kinase activation mediates kappa-opioiddependent dysphoria. J Neurosci 27:11614-11623.

Buscher HH, Hill RC, Römer D, Cardinaux F, Closse A, Hauser D, and Pless J (1976) Evidence for analgesic activity of enkephalin in the mouse. Nature 261:423-425.

Cador M, Kelley AE, Le Moal M, and Stinus L (1986) Ventral tegmental area infusion of substance P, neurotensin and enkephalin: differential effects on feeding behavior. Neuroscience 18:659-669.

Calhoun SE, Meunier CJ, Lee CA, McCarty GS, and Sombers LA (2019) Characterization of a multiple-scan-rate voltammetric waveform for real-time detection of met-enkephalin. ACS Chem Neurosci 10:2022-2032.

Chavkin C (2018) Kappa-opioid antagonists as stress resilience medications for the treatment of alcohol use disorders. Neuropsychopharmacology 43:1803-1804.

Che FY, Yuan Q, Kalinina E, and Fricker LD (2004) Examination of the rate of peptide biosynthesis in neuroendocrine cell lines using a stable isotopic label and mass spectrometry. $J$ Neurochem 90:585-594

Cone RI, Weber E, Barchas JD, and Goldstein A (1983) Regional distribution of dynorphin and neo-endorphin peptides in rat brain, spinal cord, and pituitary. $J$ Neurosci 3:2146-2152.

Cumming P, Marton J, Lilius TO, Olberg DE, and Rominger A (2019) A survey of molecular imaging of opioid receptors. Molecules 24:4190.

DiFeliceantonio AG, Mabrouk OS, Kennedy RT, and Berridge KC (2012) Enkephalin surges in dorsal neostriatum as a signal to eat. Curr Biol 22:1918-1924.

Dores RM, Liang L, Davis P, Thomas AL, and Petko B (2016) 60 YEARS OF POMC: melanocortin receptors: evolution of ligand selectivity for melanocortin peptides. J Mol Endocrinol 56:T119-T133.

D'Souza NB and Lindberg I (1988) Evidence for the phosphorylation of a proenkephalin-derived peptide, peptide B. J Biol Chem 263:2548-2552.

Duncan RR, Greaves J, Wiegand UK, Matskevich I, Bodammer G, Apps DK, Shipston MJ, and Chow RH (2003) Functional and spatial segregation of secretory vesicle pools according to vesicle age. Nature 422:176-180.

Eiden LE, Giraud P, Affolter HU, Herbert E, and Hotchkiss AJ (1984) Alternative modes of enkephalin biosynthesis regulation by reserpine and cyclic AMP in cultured chromaffin cells. Proc Natl Acad Sci USA 81:3949-3953.

Eiden LE and Zamir N (1986) Metorphamide levels in chromaffin cells increase after treatment with reserpine. J Neurochem 46:1651-1654.

Erbs E, Faget L, Scherrer G, Matifas A, Filliol D, Vonesch JL, Koch M, Kessler P, Hentsch D, Birling MC, et al. (2015) A mu-delta opioid receptor brain atlas reveals neuronal co-occurrence in subcortical networks. Brain Struct Funct 220:677-702.
Fricker LD (2004) Carboxypeptidase E, in Handbook of Proteolytic Enzymes (Barrett AJ, Rawlings ND, and Woessner JF vol, 8, pp 840-844, Academic Press, San Diego, CA. Fricker LD (2010) Analysis of mouse brain peptides using mass spectrometry-based peptidomics: implications for novel functions ranging from non-classical neuropeptides to microproteins. Mol Biosyst 6:1355-1365.

Fricker LD (2012) Neuropeptides and Other Bioactive Peptides, Morgan \& Claypool Life Sciences, Charleston, S.C.

Fricker LD (2018) Carboxypeptidase E and the identification of novel neuropeptides as potential therapeutic targets. Adv Pharmacol 82:85-102.

Fricker LD and Snyder SH (1982) Enkephalin convertase: purification and characterization of a specific enkephalin-synthesizing carboxypeptidase localized to adrenal chromaffin granules. Proc Natl Acad Sci USA 79:3886-3890.

Garrett JE and Douglass JO (1989) Human chorionic gonadotropin regulates expression of the proenkephalin gene in adult rat Leydig cells. Mol Endocrinol 3: 2093-2100.

Gerrits MA, Patkina N, Zvartau EE, and van Ree JM (1995) Opioid blockade attenuates acquisition and expression of cocaine-induced place preference conditioning in rats. Psychopharmacology (Berl) 119:92-98.

Glimcher PW, Giovino AA, Margolin DH, and Hoebel BG (1984) Endogenous opiate reward induced by an enkephalinase inhibitor, thiorphan, injected into the ventral midbrain. Behav Neurosci 98:262-268.

Gold G, Gishizky ML, and Grodsky GM (1982) Evidence that glucose "marks" beta cells resulting in preferential release of newly synthesized insulin. Science 218 $56-58$

Goldstein A, Tachibana S, Lowney LI, Hunkapiller M, and Hood L (1979) Dynorphin(1-13), an extraordinarily potent opioid peptide. Proc Natl Acad Sci USA 76: $6666-6670$

Gomes I, Aryal DK, Wardman JH, Gupta A, Gagnidze K, Rodriguiz RM, Kumar S, Wetsel WC, Pintar JE, Fricker LD, et al. (2013) GPR171 is a hypothalamic G protein-coupled receptor for BigLEN, a neuropeptide involved in feeding. Proc Natl Acad Sci USA 110:16211-16216.

Gomes I, Gupta A, Filipovska J, Szeto HH, Pintar JE, and Devi LA (2004) A role for heterodimerization of $\mathrm{mu}$ and delta opiate receptors in enhancing morphine analgesia. Proc Natl Acad Sci USA 101:5135-5139.

Gomes I, Ijzerman AP, Ye K, Maillet EL, and Devi LA (2011) G protein-coupled receptor heteromerization: a role in allosteric modulation of ligand binding. $\mathrm{Mol}$ Pharmacol 79:1044-1052.

Gomes I, Jordan BA, Gupta A, Trapaidze N, Nagy V, and Devi LA (2000) Heterodimerization of mu and delta opioid receptors: a role in opiate synergy. $J$ Neurosci 20:RC110.

Gomes I, Sierra S, Lueptow L, Gupta A, Gouty S, Margolis EB, Cox BM, and Devi LA (2020) Biased signaling by endogenous opioid peptides. Proc Natl Acad Sci USA 117:11820-11828.

Greene D, Das B, and Fricker LD (1992) Regulation of carboxypeptidase E. Effect of $\mathrm{pH}$, temperature and $\mathrm{Co} 2+$ on kinetic parameters of substrate hydrolysis. Biochem $J$ 285:613-618.

Grisel JE, Mogil JS, Grahame NJ, Rubinstein M, Belknap JK, Crabbe JC, and Low MJ (1999) Ethanol oral self-administration is increased in mutant mice with decreased beta-endorphin expression. Brain Res 835:62-67.

Gupta A, Fujita W, Gomes I, Bobeck E, and Devi LA (2015) Endothelin-converting enzyme 2 differentially regulates opioid receptor activity. $\mathrm{Br} J$ Pharmacol 172: $704-719$.

Gupta A, Gomes I, Wardman J, and Devi LA (2014) Opioid receptor function is regulated by post-endocytic peptide processing. J Biol Chem 289:19613-19626.

Hammonds RG Jr., Nicolas P, and Li CH (1984) beta-endorphin-(1-27) is an antagonist of beta-endorphin analgesia. Proc Natl Acad Sci USA 81:1389-1390.

Handa BK, Land AC, Lord JA, Morgan BA, Rance MJ, and Smith CF (1981) Analogues of beta-LPH61-64 possessing selective agonist activity at mu-opiate receptors. Eur J Pharmacol 70:531-540.

Hayward MD, Hansen ST, Pintar JE, and Low MJ (2004) Operant selfadministration of ethanol in C57BL/6 mice lacking beta-endorphin and enkephalin. Pharmacol Biochem Behav 79:171-181.

Helwig M, Vivoli M, Fricker LD, and Lindberg I (2011) Regulation of neuropeptide processing enzymes by catecholamines in endocrine cells. Mol Pharmacol 80:304-313.

Henderson G, Hughes J, and Kosterlitz HW (1972) A new example of a morphinesensitive neuro-effector junction: adrenergic transmission in the mouse vas deferens. Br J Pharmacol 46:764-766.

Hirsch MD and Millington WR (1991) Endoproteolytic conversion of beta-endorphin 1-31 to beta-endorphin-1-27 potentiates its central cardioregulatory activity. Brain Res 550:61-68.

Höllt V (1986) Opioid peptide processing and receptor selectivity. Annu Rev Pharmacol Toxicol 26:59-77.

Holzer P (2009) Opioid receptors in the gastrointestinal tract. Regul Pept 155:11-17. Hoshino A and Lindberg I (2012) Peptide Biosynthesis: Prohormone Convertases 1/3 and 2, Morgan \& Claypool Life Sciences, New Jersey.

Hughes J, Kosterlitz HW, and Smith TW (1977) The distribution of methionineenkephalin and leucine-enkephalin in the brain and peripheral tissues. $\mathrm{Br}$ $J$ Pharmacol 61:639-647.

Hughes J, Smith TW, Kosterlitz HW, Fothergill LA, Morgan BA, and Morris HR (1975) Identification of two related pentapeptides from the brain with potent opiate agonist activity. Nature 258:577-580

Kastin AJ, Scollan EL, King MG, Schally AV, and Coy DH (1976) Enkephalin and a potent analog facilitate maze performance after intraperitoneal administration in rats. Pharmacol Biochem Behav 5:691-695.

Kasukawa T, Masumoto KH, Nikaido I, Nagano M, Uno KD, Tsujino K, Hanashima C, Shigeyoshi Y, and Ueda HR (2011) Quantitative expression profile of distinct functional regions in the adult mouse brain. PLoS One 6:e23228.

Kelley AE, Cador M, Stinus L, and Le Moal M (1989) Neurotensin, substance P, neurokinin-alpha, and enkephalin: injection into ventral tegmental area in the rat produces differential effects on operant responding. Psychopharmacology (Berl) 97: 243-252. 
King MG, Kastin AJ, Olson RD, and Coy DH (1979) Systemic administration of Metenkephalin, (D-Ala2)-Met-enkephalin, beta-endorphin, and (D-Ala2)-beta-endorphin: effects on eating, drinking and activity measures in rats. Pharmacol Biochem Behav 11:407-411.

Klemperer EM, Hughes JR, and Naud S (2018) Study characteristics influence the efficacy of substance abuse treatments: a meta-analysis of medications for alcohol use disorder. Drug Alcohol Depend 190:229-234.

Kosterlitz HW (1985) The Wellcome Foundation lecture, 1982. Opioid peptides and their receptors. Proc $R$ Soc Lond B Biol Sci 225:27-40.

Kranzler HR and Soyka M (2018) Diagnosis and pharmacotherapy of alcohol use disorder: a review. JAMA 320:815-824.

Kumar D, Mains RE, and Eipper BA (2016) 60 Years of POMC: from POMC and $\alpha$-MSH to PAM, molecular oxygen, copper, and vitamin C. J Mol Endocrinol 56: T63-T76

Land BB, Bruchas MR, Lemos JC, Xu M, Melief EJ, and Chavkin C (2008) The dysphoric component of stress is encoded by activation of the dynorphin kappaopioid system. J Neurosci 28:407-414.

Lazarus LH, Ling N, and Guillemin R (1976) beta-Lipotropin as a prohormone for the morphinomimetic peptides endorphins and enkephalins. Proc Natl Acad Sci USA 73:2156-2159

Lecchi P, Loh YP, Snell CR, and Pannell LK (1997) The structure of synenkephalin (pro-enkephalin 1-73) is dictated by three disulfide bridges. Biochem Biophys Res Commun 232:800-805.

Le Merrer J, Becker JA, Befort K, and Kieffer BL (2009) Reward processing by the opioid system in the brain. Physiol Rev 89:1379-1412.

Levine JD, Gordon NC, and Fields HL (1978) The mechanism of placebo analgesia. Lancet 2:654-657.

Levine JD, Gordon NC, and Fields HL (1979) Naloxone dose dependently produces analgesia and hyperalgesia in postoperative pain. Nature 278:740-741.

Li CH (1964) Lipotropin, a new active peptide from pituitary glands. Nature 201:924.

$\mathrm{Li} \mathrm{CH}$ and Chung D (1976) Primary structure of human beta-lipotropin. Nature 260: $622-624$

Lindberg I (1986) Reserpine-induced alterations in the processing of proenkephalin in cultured chromaffin cells. Increased amidation. $J$ Biol Chem 261:16317-16322.

Lord JA, Waterfield AA, Hughes J, and Kosterlitz HW (1977) Endogenous opioid peptides: multiple agonists and receptors. Nature 267:495-499.

Lukas SE, Lowen SB, Lindsey KP, Conn N, Tartarini W, Rodolico J, Mallya G, Palmer C, and Penetar DM (2013) Extended-release naltrexone (XR-NTX) attenuates brain responses to alcohol cues in alcohol-dependent volunteers: a bold FMRI study. Neuroimage 78:176-185.

Malfroy B, Swerts JP, Guyon A, Roques BP, and Schwartz JC (1978) High-affinity enkephalin-degrading peptidase in brain is increased after morphine. Nature 276: $523-526$.

Mansour A, Hoversten MT, Taylor LP, Watson SJ, and Akil H (1995) The cloned mu, delta and kappa receptors and their endogenous ligands: evidence for two opioid peptide recognition cores. Brain Res 700:89-98.

Margolis EB, Fields HL, Hjelmstad GO, and Mitchell JM (2008) Delta-opioid receptor expression in the ventral tegmental area protects against elevated alcohol consumption. J Neurosci 28:12672-12681.

Martinez D, Slifstein M, Matuskey D, Nabulsi N, Zheng MQ, Lin SF, Ropchan J, Urban N, Grassetti A, Chang D, et al. (2019) Kappa-opioid receptors, dynorphin, and cocaine addiction: a positron emission tomography study. Neuropsychopharmacology 44:1720-1727.

McKay LD, Kenney NJ, Edens NK, Williams RH, and Woods SC (1981) Intracerebroventricular beta-endorphin increases food intake of rats. Life Sci 29:1429-1434.

McLaughlin JP, Li S, Valdez J, Chavkin TA, and Chavkin C (2006) Social defeat stress-induced behavioral responses are mediated by the endogenous kappa opioid system. Neuropsychopharmacology 31:1241-1248.

McLaughlin JP, Marton-Popovici M, and Chavkin C (2003) Kappa opioid receptor antagonism and prodynorphin gene disruption block stress-induced behavioral responses. J Neurosci 23:5674-5683.

McLean S, Rothman RB, Jacobson AE, Rice KC, and Herkenham M (1987) Distribution of opiate receptor subtypes and enkephalin and dynorphin immunoreactivity in the hippocampus of squirrel, Guinea pig, rat, and hamster. J Comp Neurol 255:497-510

Miller JD, Speciale SG, McMillen BA, and German DC (1984) Naloxone antagonism of stress-induced augmentation of frontal cortex dopamine metabolism. Eur $J$ Pharmacol 98:437-439.

Minamino N, Kangawa K, Fukuda A, Matsuo H, and Iagarashi M (1980) A new opioid octapeptide related to dynorphin from porcine hypothalamus. Biochem Biophys Res Commun 95:1475-1481.

Mitchell JM, O'Neil JP, Jagust WJ, and Fields HL (2013) Catechol-O-methyltransferase genotype modulates opioid release in decision circuitry. Clin Transl Sci 6:400-403.

Miyata A, Mizuno K, Minamino N, and Matsuo H (1984) Regional distribution of adrenorphin in rat brain: comparative study with PH-8P. Biochem Biophys Res Commun 120:1030-1036

Mogil JS, Grisel JE, Hayward MD, Bales JR, Rubinstein M, Belknap JK, and Low MJ (2000) Disparate spinal and supraspinal opioid antinociceptive responses in betaendorphin-deficient mutant mice. Neuroscience 101:709-717.

Mosberg HI, Hurst R, Hruby VJ, Gee K, Akiyama K, Yamamura HI, Galligan JJ, and Burks TF (1983) Cyclic penicillamine containing enkephalin analogs display profound delta receptor selectivities. Life Sci 33 (Suppl 1):447-450.

Myrick H, Anton RF, Li X, Henderson S, Randall PK, and Voronin K (2008) Effect of naltrexone and ondansetron on alcohol cue-induced activation of the ventral striatum in alcohol-dependent people. Arch Gen Psychiatry 65:466-475.

Navratilova E, Ji G, Phelps C, Qu C, Hein M, Yakhnitsa V, Neugebauer V, and Porreca F (2019) Kappa opioid signaling in the central nucleus of the amygdala promotes disinhibition and aversiveness of chronic neuropathic pain. Pain 160: 824-832.
Nguyen K, Tseng A, Marquez P, Hamid A, and Lutfy K (2012) The role of endogenous dynorphin in ethanol-induced state-dependent CPP. Behav Brain Res 227: $58-63$

Nicolas $\mathrm{P}$ and Li CH (1985) Beta-endorphin-(1-27) is a naturally occurring antagonist to etorphine-induced analgesia. Proc Natl Acad Sci USA 82:3178-3181.

Noel G and Mains RE (1991) The ordered secretion of bioactive peptides: oldest or newest first? Mol Endocrinol 5:787-794.

Page S, Mavrikaki MM, Lintz T, Puttick D, Roberts E, Rosen H, Carroll FI, Carlezon WA, and Chartoff EH (2019) Behavioral pharmacology of novel kappa opioid receptor antagonists in rats. Int $J$ Neuropsychopharmacol 22:735-745.

Pan ZZ, Tershner SA, and Fields HL (1997) Cellular mechanism for anti-analgesic action of agonists of the kappa-opioid receptor. Nature 389:382-385.

Parker KE, Pedersen CE, Gomez AM, Spangler SM, Walicki MC, Feng SY, Stewart SL, Otis JM, Al-Hasani R, McCall JG, et al. (2019) A paranigral VTA nociceptin circuit that constrains motivation for reward. Cell 178 (3):653-671.e19.

Perazzo J, Castanho MA, and Sá Santos S (2017) Pharmacological potential of the endogenous dipeptide kyotorphin and selected derivatives. Front Pharmacol 7:530. Phillips AG, LePiane FG, and Fibiger HC (1983) Dopaminergic mediation of reward produced by direct injection of enkephalin into the ventral tegmental area of the rat. Life Sci 33:2505-2511.

Pomeranz B and Chiu D (1976) Naloxone blockade of acupuncture analgesia: endorphin implicated. Life Sci 19:1757-1762.

Robble MA, Bozsik ME, Wheeler DS, and Wheeler RA (2020) Learned avoidance requires VTA KOR-mediated reductions in dopamine. Neuropharmacology 167: 107996.

Rubinstein M, Mogil JS, Japón M, Chan EC, Allen RG, and Low MJ (1996) Absence of opioid stress-induced analgesia in mice lacking beta-endorphin by site-directed mutagenesis. Proc Natl Acad Sci USA 93:3995-4000.

Sando H, Borg J, and Steiner DF (1972) Studies on the secretion of newly synthesized proinsulin and insulin from isolated rat islets of Langerhans. $J$ Clin Invest 51: 1476-1485.

Schacht JP, Randall PK, Latham PK, Voronin KE, Book SW, Myrick H, and Anton $\mathrm{RF}$ (2017) Predictors of naltrexone response in a randomized trial: reward-related brain activation, OPRM1 genotype, and smoking status. Neuropsychopharmacology 42:2640-2653.

Schafer MK, Day R, Watson S, and Akil H (1991) Distribution of opioids in brain and peripheral tissues, in Neurobiology of Opioids (Almeida OFX and Shippenberg TS 53-74, Springer-Verlag, Berlin.

Schaumann W (1955) The paralysing action of morphine on the Guinea-pig ileum. $\mathrm{Br}$ $J$ Pharmacol Chemother 10:456-461.

Schmidt AC, Dunaway LE, Roberts JG, McCarty GS, and Sombers LA (2014) Multiple scan rate voltammetry for selective quantification of real-time enkephalin dynamics. Anal Chem 86:7806-7812.

Schmitt S, Delamare J, Tirel O, Fillesoye F, Dhilly M, and Perrio C (2017) N-[ $\left.{ }^{18} \mathrm{~F}\right]-$ FluoropropylJDTic for $\kappa$-opioid receptor PET imaging: radiosynthesis, pre-clinical evaluation, and metabolic investigation in comparison with parent JDTic. Nucl Med Biol 44:50-61.

Seizinger BR, Grimm C, Höllt V, and Herz A (1984) Evidence for a selective processing of proenkephalin $\mathrm{B}$ into different opioid peptide forms in particular regions of rat brain and pituitary. $J$ Neurochem 42:447-457.

Seizinger BR, Liebisch DC, Gramsch C, Herz A, Weber E, Evans CJ, Esch FS, and Böhlen P (1985) Isolation and structure of a novel C-terminally amidated opioid peptide, amidorphin, from bovine adrenal medulla. Nature 313:57-59.

Shippenberg TS, Herz A, Spanagel R, Bals-Kubik R, and Stein C (1992) Conditioning of opioid reinforcement: neuroanatomical and neurochemical substrates. Ann NY Acad Sci 654:347-356.

Sonders M and Weber E (1987) Distribution pattern of metorphamide compared with other opioid peptides from proenkephalin and prodynorphin in the bovine brain. $J$ Neurochem 49:671-680.

Stern AS, Lewis RV, Kimura S, Rossier J, Gerber LD, Brink L, Stein S, and Udenfriend $S$ (1979) Isolation of the opioid heptapeptide Met-enkephalin [Arg6,Phe7] from bovine adrenal medullary granules and striatum. Proc Natl Acad Sci USA 76:6680-6683.

Svingos AL, Cheng PY, Clarke CL, and Pickel VM (1995) Ultrastructural localization of delta-opioid receptor and Met5-enkephalin immunoreactivity in rat insular cortex. Brain Res 700:25-39.

ter Riet G, de Craen AJ, de Boer A, and Kessels AG (1998) Is placebo analgesia mediated by endogenous opioids? A systematic review. Pain 76:273-275.

Thompson GL, Lane JR, Coudrat T, Sexton PM, Christopoulos A, and Canals M (2015) Biased agonism of endogenous opioid peptides at the $\mu$-Opioid receptor. $M o l$ Pharmacol 88:335-346.

Toll L, Bruchas MR, Calo' G, Cox BM, and Zaveri NT (2016) Nociceptin/orphanin FQ receptor structure, signaling, ligands, functions, and interactions with opioid systems. Pharmacol Rev 68:419-457.

Trujillo KA, Belluzzi JD, and Stein L (1991) Naloxone blockade of amphetamine place preference conditioning. Psychopharmacology (Berl) 104:265-274.

Tseng A, Nguyen K, Hamid A, Garg M, Marquez P, and Lutfy K (2013) The role of endogenous beta-endorphin and enkephalins in ethanol reward. Neuropharmacology 73:290-300.

Tuteja R (2005) Type I signal peptidase: an overview. Arch Biochem Biophys 441: 107-111.

Uhlén M, Fagerberg L, Hallström BM, Lindskog C, Oksvold P, Mardinoglu A, Sivertsson A, Kampf C, Sjöstedt E, Asplund A, et al. (2015) Proteomics. Tissuebased map of the human proteome. Science 347:1260419.

Ulett GA, Han S, and Han JS (1998) Electroacupuncture: mechanisms and clinical application. Biol Psychiatry 44:129-138.

Valenca MM and Negro-Vilar A (1986) Proopiomelanocortin-derived peptides in testicular interstitial fluid: characterization and changes in secretion after human chorionic gonadotropin or luteinizing hormone-releasing hormone analog treatment. Endocrinology 118:32-37. 
Walker BM and Koob GF (2008) Pharmacological evidence for a motivational role of kappa-opioid systems in ethanol dependence. Neuropsychopharmacology $\mathbf{3 3}$ 643-652.

Weber E, Esch FS, Böhlen P, Paterson S, Corbett AD, McKnight AT, Kosterlitz HW, Barchas JD, and Evans CJ (1983) Metorphamide: isolation, structure, and biologic activity of an amidated opioid octapeptide from bovine brain. Proc Natl Acad Sci USA 80:7362-7366.

Weber E, Evans CJ, and Barchas JD (1982) Predominance of the amino-terminal octapeptide fragment of dynorphin in rat brain regions. Nature 299:77-79.

Wilson SP, Chang KJ, and Viveros OH (1980) Synthesis of enkephalins by adrenal medullary chromaffin cells: reserpine increases incorporation of radiolabeled amino acids. Proc Natl Acad Sci USA 77:4364-4368.

Windisch KA, Reed B, and Kreek MJ (2018) Naltrexone and nalmefene attenuate cocaine place preference in male mice. Neuropharmacology 140:174-183.
Xie JY, De Felice M, Kopruszinski CM, Eyde N, LaVigne J, Remeniuk B, Hernandez P, Yue X, Goshima N, Ossipov M, et al. (2017) Kappa opioid receptor antagonists: a possible new class of therapeutics for migraine prevention. Cephalalgia 37:780-794 Yu B and Millhauser GL (2007) Chemical disulfide mapping identifies an inhibitor cystine knot in the agouti signaling protein. FEBS Lett 581:5561-5565.

Zadina JE, Hackler L, Ge LJ, and Kastin AJ (1997) A potent and selective endogenous agonist for the mu-opiate receptor. Nature 386:499-502.

Zhou A, Webb G, Zhu X, and Steiner DF (1999) Proteolytic processing in the secretory pathway. J Biol Chem 274:20745-20748.

Address correspondence to: Dr. Lloyd Fricker, Department of Molecular Pharmacology, Albert Einstein College of Medicine, 1300 Morris Park Ave, Bronx, NY 10461. E-mail: Lloyd.Fricker@Einsteinmed.org 